\title{
COMPARISON OF GOOD CORPORATE GOVERNANCE(GCG) IMPLEMENTATION PRACTICES IN ISLAMIC COMMERCIAL BANKS IN INDONESIA
}

\author{
Hendra Eka Saputra1, Zul Ihsan ${ }^{2}$ \\ ${ }^{1}$ Universitas Islam Riau, \\ ${ }^{2}$ Universitas Islam Negeri Sultan Thaha Saifuddin \\ Email : hendraekasaputra@fis.uir.ac.id, zihsan14@gmail.com
}

\begin{abstract}
Sharia Banking in Indonesia has a Sharia Supervisory Board that can monitor the operation of Sharia banks so that they are different from other banks. It is hoped that with this monitoring system the operation of corporate governance will be better. This study aims to explain the differences in the application of Good Corporate Governance (GCG) between Islamic banking in Indonesia. Sharia Bank is a bank whose application is different from conventional banks. Where one of the differences is the existence of a Sharia Supervisory Board which ensures bank activities are based on sharia. Then conducted a study of Islamic banks during 2014 to 2018. This research method uses descriptive analysis based on data that has been reported by each Islamic banking. The results of the survey showed that BCA Syariah and BSM received the highest rating among other sharia banks. This explanation shows that the implementation of corporate governance has been "very good" and has been in accordance with the stipulated provisions. BNIS, BRIS, Bukopin Syariah Bank, Mega Syariah Bank, Panin Syariah Bank, Victoria Syariah Bank, and Maybank Syariah, each ranked 2 (two). This means that the implementation of corporate governance goes "well". Interestingly, the Muamalat bank which has been the oldest BUS in Indonesia is ranked 3 (three). This means that the application of corporate governance is "good enough". Some notes on Muamalat's bank that must be corrected.
\end{abstract}

Keyword : Islamic Banks, Good Corporate Governance 


\section{INTRODUCTION}

Company control is an issue that cannot be separated by companies from various parties. This is done so that the creation of independence for managers in producing maximum company performance. Management of the company by professionals is carried out separately between the parties concerned. So there is a control function between the company's organs (GMS, Directors, and Board of Commissioners). In addition to independence, the principle of openness is also important in creating a healthy business environment. Transparency is carried out to maintain a balance of information gaps between shareholders and management. With transparency, shareholders will be able to assess how the company's performance is invested by looking at how the financial statements are performing (Ben \& Padilla Angulo, L. 2018: 231).

The relationship between the decision maker and management is based on the assumption that management acts based on its interests at the expense of the interests of shareholders (agency theory) (Patel, et.al, 2018: 286). Agency conflicts that arise are caused by various things, such as Moral-Hazard, Earning Retention, Risk Conversion, and TimeHorizon. This assumption was built to prevent the gap between shareholders and management, where the owner has an interest in getting the maximum return, while the manager has an interest in incentives for fund management (Athari, et.al, 2016: 101-103).

\section{LITERATURE REVIEW}

The corporate governance system was built to regulate the authority of directors so as not to abuse authority and ensure to work only for the benefit of the company (Alandejani, et.al, 2017: 136).
Corporate governance is carried out to monitor company management in various industries, such as banking, capital markets, and other companies. The rules of corporate governance not only pay attention to how the company's business is running, but also about overall supervision and control of the company including the directors' policies. So that in corporate governance must include four principles in order to run properly, namely Direction, Executive action, Supervision, and Accountability. These four principles are important points for companies with the expectation of company compliance with regulations and minimizing gaps (Ducassy \& Montandrau, 2015: 389).

Companies that practice good governance show that the monitoring function of board members is increasing. Resulting in effective managerial decisions and improved performance. This effectiveness signifies the manager's opportunistic behavior which is reduced in manipulating reported earnings, due to the manager's tendency towards managing opportunistic financial statements. Even some well-managed companies exhibit lower levels of default risk (Alexakis, et.al, 2019: 13). Overall corporate governance practices themselves affect company performance. The implication is that it creates cohesiveness between managers and shareholders in conducting their business effectively in accordance with the rules of management guidelines (Hassan, et.al, 2019: 20).

The implementation of Good Corporate Governance (GCG) in Indonesia also began with the signing of a memorandum of agreement between Indonesia and the IMF in line with the formation of the National Committee on Corporate Governance Policy (KNKCG) 
which formulated guidelines for Good Corporate Governance (GCG) issues in Indonesia to be implemented by companies operating in Indonesia. On November 29, 2000 the guidelines were formalized based on the decision of the Coordinating Minister for the Economy no. 31 / M.Ekuin / 06/2000, which recommends improvements to the rules for implementing the guidelines (Iqbal, et.al, 2015:46-48).

Basically the Good Corporate Governance (GCG) principle is a choice in carrying out economic activities. However, these principles create good governance and increase value in the company. Seeing the importance of implementing Good Corporate Governance (GCG), the role of public institutions as regulators is needed as a benchmark for Good Corporate Governance (GCG) such as courts, the Capital Market Supervisory Agency, Bank Indonesia, and other institutions. This principle should be carried out by limited liability companies, state-owned companies, banking institutions, and other institutions where Good Corporate Governance (GCG) is needed.

The banking institution it self has implemented the Good Corporate Governance (GCG) principles dated 30 January 2006 as stipulated in Bank Indonesia regulation no.8 / 4 / PBI / 2006. Where this regulation aims to strengthen banking conditions in the face of risk, protect the interests of stakeholders, and improve compliance with applicable laws in the banking industry.

\section{METHOD}

This type of research uses descriptive qualitative with library studies with the development of ideas from the quoted theory.

\section{RESULTS AND DISCUSSION}

Related to the risks faced by banks, that banks face credit risks (both in financing and in the form of debt) that depend on the management system (J. Li, C., Li, Dkk,2017: 47). Where in Indonesia there are two different banking systems so that the risks faced are also different. Islamic banks in managing risk are better than conventional banks, especially when the global financial crisis makes Islamic banks more efficient than conventional banks, as well as efficiency better fees than conventional banks. Indeed, after the crisis period, the development of Islamic banks has increased with some evidence that Islamic banks are resistant to financial crises, even Islamic bank financing has increased compared to conventional bank loans. Even Islamic banks are more profitable than conventional banks based on bank financial statements. In another analysis also shows that Islamic banks are more resilient than conventional banks, seen from the high volatility of conventional banks. Problems that exist at the time of the crisis that befell the national banking world, namely Negative spread, Liquidity, NOP (net open position), NPL (NonPerforming Loans) and Capital (Capital) (Neifar \& Jarboui, 2018: 44).

However, other facts show that the cost and profit performance of Islamic banks is worse than conventional banks. Indeed during the crisis, Islamic banks are resistant to shocks, but during the end of the crisis period, financial instability of Islamic banks is higher than conventional banks coupled with poorer performance with a decrease in capital, profitability, and efficiency. On the other hand, there are differences in efficiency between the two banks which show conventional banks are more efficient than Islamic banks. This means that conventional 
banks are more efficient in managing costs than Islamic banks. The failure rate of Islamic banks is also higher than conventional banks, which indicates that the resilience of Islamic banks has not been stable so that the sustainability of Islamic banks is shorter. Agency problems are also seen that conventional banks are relatively less and the tendency for Islamic banks to have agency problems .

Seeing the above phenomenon, that on one hand, Islamic banks are better than conventional banks, but on the other hand vice versa. It needs to be seen how the practice of implementing Good Corporate Governance (GCG) in Islamic banks, where corporate governance practices can improve company performance which ultimately affects the value of the company.

This study differs from previous studies that looked at the effect of Good Corporate Governance (GCG) implementation on Islamic banks. This study wants to see how the implementation of Good Corporate Governance (GCG) itself in Islamic Commercial Banks in Indonesia. Indeed, at the time of the financial crisis, Islamic banks have more resilience than conventional banks, but from several studies show that Islamic banks after the financial crisis showed lower performance than conventional banks. Several causes can affect the decline in the quality of Islamic banks, one of which is how the implementation of corporate governance in Islamic banks themselves.

Corporate Governance is a system that is carried out to achieve the balance of the company as a continuation of its existence, which in principle there are several universal aspects contained in each guideline, namely Corporate Objective, Voting Right, Non-executive Corporate Board, Corporate
Remuneration Policies, Strategic Focus, Operating Performance, Shareholders Returns, and Corporate Citizenship. So, the existing guidelines in a country must be applied by the company in the country concerned. Because this principle becomes very important in order to prevent the practice of inequality that will occur.

Within the scope of the bank, Good Corporate Governance (GCG) applies the principles of transparency, accountability, responsibility, independence and fairness, which in its implementation carries out the functions of internal control, application of the compliance function, internal and external auditors, application of risk management, and transparency of bank financial conditions.

In general, Islamic banks must have two main principles, namely the AtTa'awun Principle and the Principles of Avoiding Al-Ikhtinaz. In the ta'awun principle, Islamic banks have a social purpose in helping the surrounding community. In practice Islamic banks can implement Corporate Social Responsibility (CSR) or Qardhul Hasan. In avoiding Al-Ikhtinaz, Islamic banks are demanded not to practice the Maghrib (Maysir, Gharar, and Riba), which is forbidden in Islam. The system is prohibited, it is hoped that there will be no speculative and manipulative practices that can destroy the economy. So based on general principles that must exist in Islamic banks, Islamic banks are expected to run good governance practices.

The implementation of corporate governance encourages companies to practice good corporate governance. Where in governance which consists of five aspects includes eight principles of good corporate governance and 25 recommendations for the application of aspects of corporate governance. This 
rule also includes guidelines for shareholders, the Board of Commissioners, the Board of Directors, the Sharia Supervisory Board, and other committees contained in the banking structure. Assessments will be made to each official, such as how meetings are held in each of his cabinet, how the company communicates with shareholders or investors, clarifies the function and role of the board of commissioners, how should the quality of the directors' duties be carried out, how is stakeholder participation, and information disclosure (H. Ibrahim, M. \& Rizvi, S. A. R, 2018: 33). So that the oversight function is clearly illustrated by various assessments of those who make decisions. These Good Corporate Governance (GCG) principles must be carried out continuously so that interaction in all organs of the company is maximized based on laws and regulations and articles of association (Effendi, 2016: 34-35).

Banking problems are very complex due to various risks faced, so the need for Good Corporate Governance (GCG) practices is very much needed. Given that banks manage public funds that are vulnerable to various obstacles. Based on the regulations that have been made, it is expected to minimize deviation by both the directors and shareholders. Where the regulation aims to improve banking performance for the better and healthier. For this reason, banks need to be managed by people who have high competence and integrity in meeting the statutory requirements.

Transparency is needed to clarify the benefits and risks of the product and increase customer protection. This is done to reduce the information asymmetry of bank obligations in conveying information to customers so that there is no misdirection and dissemination of customer personal data. In increasing transparency, Bank Indonesia circulated letters to all commercial banks in Indonesia no.15 / 15 / DPNP on April 29, as well as the Financial Services Authority (OJK) regulation no.6 / POJK.03 / 2015 dated March 31, 2015 concerning transparency and publication of bank statements. This regulation is carried out so that the financial condition and performance of banks become healthier and increase the confidence of customers and investors due to the submission of financial information that is not in doubt anymore (Nazir, \& Afza, 2018: 139-141).

The principle of transparency is very important for the public in making decisions based on relevant information related to company conditions. The company will provide an annual report which is the company's fundamentals. Based on PP no. 24 of 1998, that financial transparency creates efficiency and increases competitiveness. Where companies are required to submit company financial statements, because customers need information disclosure. Banking itself is a financial institution that manages public funds, so banks should provide relevant, accurate, balanced and continuous information. The information needed is mainly in operational risk, because this information is the relevant value used by investors as additional information on bank risk assessments (Fakhfekh, et.al, 2016:85).

Banking supervision also plays a role in the audit committee. So The Financial Services Authority (OJK) has to supervise bank managers so that there are no conflicts of interest that can harm various parties. Screening is done by looking at the track record of the council, whether it has ever committed an act of 
violation of the law or the prevention of concurrent positions that could reduce the function of the council itself. Restructuring is also needed to improve company performance and efficiency.

Financial transparency is a good form of supervision for the company. as an implication of the Good Corporate Governance (GCG) practices carried out. In the end, companies that run Good Corporate Governance (GCG) well, will continue to survive with a long life cycle as a result of the company's disclosure, investment, funding, and social responsibility such as increasing Corporate Social Responsibility (CSR) by managers, which indirectly increases company value in competitive industries. Because between corporate governance and corporate values there is a positive relationship. This means that the better corporate governance, the more value the company has in the market. Other impacts arising from effective corporate governance mechanisms are policies that do not violate the law. And limit excessive risk taking. Where this becomes important in building stable economic conditions. In order to avoid a crisis that can harm all people in a country (Majid Abdul, et.al, 2017: 1327).

Islamic banks, which in fact are banks that apply sharia principles, should have a good governance function as a corporate need, because it is in line with Islamic values, such as tabligh which means to convey what should be. In addition, Islamic banking itself has a Sharia Supervisory Board that is not owned by conventional banking. Based on MUI Decree Number Kep-98 / MUI / III / 2001, that the National Sharia Council was formed by the MUI for efficient coordination of ulama in dealing with economic and financial problems. Where the function of the Sharia Supervisory
Board oversees the application of compliance with sharia principles in banking activities as evidenced by the submission of supervisory reports within a certain period of time to DSN-MUI and the Financial Services Authority (Habib, \& Hasan, M, 2019: 189-190).

Another organ related to supervision is the Board of Commissioners. Where the board of commissioners conduct general oversight of directors. The board of commissioners in carrying out their duties must be in accordance with the principles of Good Corporate Governance (GCG) that are stipulated in the guidelines and rules which are binding, including the implementation of articles of association and resolutions of the GMS and legislation. Other activities include providing advice to directors relating to the management of the bank, preparation of vision and mission, as well as other bank's strategic plans. The assessment will continue to be carried out by examining the reports of directors in the development of the bank, both internal and external information. Because of that the board of commissioners held a meeting both with the board of commissioners and with the directors by assessing the effectiveness of internal control, assessing competence, examining the duties and authority of the independence of internal auditors based on internal audit implementation standards and external auditors based on their scope. The board of commissioners has the right to request information about the company so that directors must be transparent in presenting information regarding company conditions. Also as a precaution that the board of commissioners must not be influenced by various parties. As there is no affiliation of various parties. In anticipation of this 
information asymmetry, we need guidelines that regulate how each organ should perform its functions and responsibilities in the form of Good Corporate Governance (GCG) rules. Because, the board of this company has their respective interests. Shareholders want returns while managers have their own interests (Connelly, et.al, 2017:102).

\section{CONCLUSION}

From the results of the discussion, it was found that each BUS has a different rating. BCA Syariah and BSM get one (one) rating. This means that the implementation of corporate governance has been "very good" and has complied with the stipulated provisions. BNIS, BRIS, Bank Bukopin Syariah, Bank Mega Syariah, Bank Panin Syariah, Bank Victoria Syariah, and Maybank Syariah each received 2 (two) ratings. This means that the implementation of corporate governance is going "well". Interestingly, Muamalat bank, which has been the oldest BUS in Indonesia, was ranked 3 (three). This means that the implementation of corporate governance is "good enough". Some notes on Muamalat bank that must be corrected. How is the implementation of banking activities so far.

This paper is a record for Islamic banking in Indonesia in order to compete with conventional banking which still dominates. If the implementation of governance in Islamic banking is good, it is possible that Islamic banking in Indonesia will experience significant development and will match Islamic banking in Malaysia.

\section{REFERENCES}

Alandejani, M., Kutan, A. M., \& Samargandi, N. (2017). Do Islamic banks fail more than conventional banks?. Journal of International Financial Markets, Institutions and Money, 50, 135-155.

Alexakis, C., Izzeldin, M., Johnes, J., \& Pappas, V. (2019). Performance and productivity in Islamic and conventional banks: Evidence from the global financial crisis. Economic Modelling, 79, 1-14.

Athari, S. A., Adaoglu, C., \& Bektas, E. (2016). Investor protection and dividend policy: The case of Islamic and conventional banks. Emerging Markets Review, 27, 100-117.

Slimane, F. B., \& Angulo, L. P. (2019). Strategic change and corporate governance: Evidence from the stock exchange industry. Journal of Business Research, 103, 206-218.

Connelly, J. T., Limpaphayom, P., Nguyen, H. T., \& Tran, T. D. (2017). A tale of two cities: Economic development, corporate governance and firm value in Vietnam. Research in International Business and Finance, 42, 102-123.

Ducassy, I., \& Montandrau, S. (2015). Corporate social performance, ownership structure, and corporate governance in France. Research in International Business and Finance, 34, 383-396.

Effendi, Muh. A. (2016). The Power of Good Corporate Governance: Teori dan Implementation. Jakarta: Salemba Empat.

Fakhfekh, M., Hachicha, N., Jawadi, F., Selmi, N., \& Cheffou, A. I. (2016). Measuring volatility persistence for conventional and Islamic banks: An FI-EGARCH approach. Emerging Markets Review, 27, 84-99.

Habib, A., \& Hasan, M. M. (2019). Corporate life cycle research in accounting, finance and corporate governance: A survey, and 
directions for future research. International Review of Financial Analysis, 61, 188-201.

Hassan, M. K., Khan, A., \& Paltrinieri, A. (2019). Liquidity risk, credit risk and stability in Islamic and conventional banks. Research in International Business and Finance, 48, 17-31.

Iqbal, J., Strobl, S., \& Vähämaa, S. (2015). Corporate governance and the systemic risk of financial institutions. Journal of Economics and Business, 82, 42-61.

Abdul-Majid, M., Falahaty, M., \& Jusoh, M. (2017). Performance of Islamic and conventional banks: A meta-frontier approach. Research in International Business and Finance, 42, 1327-1335

Nazir, M. S., \& Afza, T. (2018). Does managerial behavior of managing earnings mitigate the relationship between corporate governance and firm value? Evidence from an emerging market. Future Business Journal, 4(1), 139-156.

Neifar, S., \& Jarboui, A. (2018). Corporate governance and operational risk voluntary disclosure: Evidence from Islamic banks. Research in International Business and Finance, 46, 43-54.

Patel, P. C., Guedes, M. J., Soares, N., \& da Conceição Gonçalves, V. (2018). Strength of the association between R\&D volatility and firm growth: The roles of corporate governance and tangible asset volatility. Journal of Business Research, 88, 282-288. 